\title{
INTENSITAS SERANGAN HAMA DAN PATOGEN PADA AGROEKOSISTEM HIDROPONIK TANAMAN PADI (Oryza sativa L.) DENGAN BERBAGAI MEDIA TANAM
}

\author{
Ahmad Afrizal, Suskandini Ratih D., Muhammad Nurdin \& F.X. Susilo \\ Jurusan Agroteknologi, Fakultas Pertanian, Universitas Lampung \\ Jl. Prof. Soemantri Brojonegoro, No. 1 Bandar Lampung 35145 \\ Email: afrizalahmad889@gmail.com
}

\begin{abstract}
ABSTRAK
Tujuan penelitian adalah untuk mengetahui serta menghitung intensitas serangan hama dan patogen tanaman padi (Oryza sativa L.) pada berbagai media tanam dengan sistem hidroponik. Penelitian ini dilaksanakan di desa Natar, Dusun II kecamatan Natar kabupaten Lampung Selatan pada bulan Mei sampai Juli 2016 dengan penelitian pendahuluan yang sudah dilakukan pada bulan Mei sampai Juni 2015. Penelitian ini menggunakan rancangan acak kelompok dengan media tanam sebagai perlakuan. Perhitungan intensitas serangan hama dan patogen dilakukan dengan menghitung kejadian penyakit maupun hama di setiap rumpun padi di berbagai media tanam yang berbeda-beda. Media tanam padi yang digunakan untuk sistem hidroponik adalah kontrol (K) berupa tanah sawah, arang sekam (AS), pasir malang+arang sekam (PM+AS), dan pasir malang (PM). Setiap media tanam yang berbeda di masukkan pada 12 kotak tanam padi. Setiap kotak diulang sebanyak tiga kali sehingga terdapat 12 sampel tanaman padi yang diamati hama dan penyakitnya. Hasil penelitian menunjukkan bahwa patogen yang menyerang tanaman padi dengan sistem hidroponik pada berbagai media tanam adalah penyakit bercak daun sempit dan bercak cokelat sedangkan serangga pada tanaman padi dengan sistem hidroponik dengan berbagai media tanam adalah belalang dan wereng. Penggunan media tanam arang sekam dengan sistem hidroponik menghasilkan intensitas keparahan penyakit lebih rendah dari media tanam lainnya pada dua jenis penyakit yang teridentifikasi.
\end{abstract}

Kata kunci: Media Tanam, Padi, Sistem Hidroponik

\section{PENDAHULUAN}

Padi (Oryza sativaL.) merupakan bahan pangan utama di Indonesia yang dimanfaatkan untuk pemenuhan kebutuhan karbohidrat. Indonesia merupakan negara berkembang yang termasuk ke dalam benua Asia. Pesatnya pertumbuhan penduduk di Indonesia yaitu sekitar 250 juta jiwa menyebabkan kebutuhan pangan perkapitanya cukup tinggi. Akan tetapi,produksi yag dihasilkan dan kebutuhan padi kering giling untuk memenuhi pangan di Indonesia mengalami kekurangan (BPS, 2014) .

Luas lahan padi sawah di Indonesia sekarang ini mencapai $11,79 \%$. Seiring bertambahnya jumlah penduduk di Indonesia maka kebutuhan akan pembangunan perumahan terus bertambah yang mencapai 15 juta pada tahun 2014. Hal itu menyebabkan luas lahan di Indonesia untuk penanaman padi sawah semakin menurun (BPS, 2014) $)^{\mathrm{b}}$. Penyempitan lahan untuk bercocok tanam menyebabkan hasil produksi pangan tidak mampu mencukupi kebutuhan pangan penduduk Indonesia yang semakin meningkat. Menutut Arteca (2006), hidroponik adalah suatu metode cocok tanam dimana kebutuhan unsur hara tanaman disediakan oleh larutan nutrisi yang dilarutkan ke dalam air. Sistem hidroponik diklasifikasikan kedalam dua jenis yaitu sistem substrat dan sistem tanpa substrat. Selain itu, tanaman dengan sistem hidroponik tidak merusak tanah, dan tidak membutuhkan tempat yang luas, lebih hemat karena tidak perlu menyiram air setiap hari, pertumbuhan tanaman lebih cepat dan kualitas hasil dapat terjaga (Program Kreatifitas Mahasiswa, 2014).

Pasir malang memiliki pori-pori berukuran besar (pori-pori makro) maka pasir menjadi mudah basah dan cepat kering oleh proses penguapan. Sekam padi adalah kulit biji padi yang sudah digiling dan dibakar sehingga tidak perlu disterilisasi lagi karena mikroba patogen telah mati selama proses pembakaran. Sekam bakar memiliki kandungan $\mathrm{C}$ yang tinggi sehinggga membuat media tanam ini menjadi gembur (Tim tani mandiri, 2010)

Pemilihan varietas yang tepat dan penanganan faktor lingkungan yang baik akan menjadi kunci keberhasilan dalam suatu proses budidaya. Beberapa faktor lingkungan yang terkadang menjadi penyebab kegagalan produksipada sistem hidroponik adalah tidak rapatnya plastik dan screnview, kekeringan nutrisi, atau 
serangan hama dan penyakit tanaman (Tim Tani Mandiri, 2010). Tujuan dari penelitian ini adalah mengetahui serta menghitung intensitas serangan hama dan patogen tanaman padi pada berbagai media tanam dengan sistem hidroponik, serta mengetahui hasil bobot biji padi pada sistem hidroponik.

\section{BAHAN DAN METODE}

Penelitian dilaksanakan di Dusun II, desa Natar, kecamatan Natar Kabupaten Lampung Selatan sejak bulan Mei sampai Juli 2016. Penelitian pendahuluan dilakukan pada bulan Mei sampai Juni 2015. Alat-alat yang digunakan pada penelitian adalah gelas ukur, ember, gayung, selang air, ATK, Mikroskop stereo, buku panduan, dan adukan. Bahan-bahan yang digunakan pada penelitian ini adalah arang sekam, pasir+arang sekam, pasir malang, benih padi ciherang, AB mix, dan air. Rancangan yang digunakan adalah rancangan acak kelompok dengan media tanam sebagai perlakuan. Media tanam padi yang digunakan untuk sistem hidroponik adalah kontrol (K), arang sekam (AS), pasir malang+arang sekam $(\mathrm{PM}+\mathrm{AS})$, dan pasir malang (PM). Adapun tata laksana dalam penelitian tanaman hidroponik padi adalah:

(1) Penyampuran larutan $\mathrm{AB}$ mix.

Mengukur larutan stok A dan Stok B dengan menggunakan alat berupa TDS, TDS merupakan alat untuk menghitung berapa kebutuhan nutrisi untuk tanaman. Tanaman padi membutuhkan nutrisi AB mix $1400 \mathrm{ppm}$. Apabila larutan nutrisi $<1400 \mathrm{ppm}$ maka yang ditambah adalah nutrisi AB mix. $>1400$ ppm maka yang ditambah yaitu air agar sampai $1400 \mathrm{ppm}$.

(2) Penyemaian

Wadah semai disiapkan dengan media setebal 5$7 \mathrm{~cm}$. Wadah semai diletakkan di tempat yang terkena sinar matahari tiap pagi 1-2 jam agar perkecambahan dapat tumbuh dengan baik dan sehat. Benih yang berkecambah disirami dengan air biasa secara pelanpelan. Setelah bibit berumur 15-17 hari, tanaman dipindah ke kotak plastik yang telah disediakan. Setiap kotak plastik terdiri empat tanaman padi.

(3) Kotak plastik/ Wadah Media Tanam

Membuat kerangka dinding dengan bambu-bambu yang dibelah 4 dengan posisi horizontal yang dipaku pada bambu bulat. Langkah terakhir dipasang plastik sebagai wadah media tanam yang dipaku pada bambu-bambu belah.

(4) Penuangan $A B$ mix

Nutrisi $A B$ mix diukur dengan menggunakan alat berupa TDS 1400 ppm. Setiap kotak plastik dituangkan
Nutrisi AB mix sebanyak empat gayung berukuran 1 liter pada masing-masing media tanam yang sudahadatanaman. Penggantian Nutrisi AB mix dilakukan selama 3 hari sekali.

(5) Pengamatan Hama dan Penyakit Tanaman

Gejala penyakit tanaman padi dan diindentifikasi patogennya secara mikroskopis, selanjutnya difoto dan dicocokkan dengan buku Barnet (1969). Pengamatan hama tanaman padi didasarkan pada buku Lembaga Penelitian Padi Internasional (1995). Perhitungan intensitas penyakit dengan keparahan penyakit menggunakan perhitungan rumus sebagai berikut (Ginting, 2013) (Tabel 1).

$$
\mathrm{PP}=\frac{\sum(\mathrm{n} \times \mathrm{v})}{\mathrm{N} \times \mathrm{V}} \times 100 \%
$$

Keterangan :

$\mathrm{KP}=$ Keparahan Penyakit (\%)

$\mathrm{n}=$ Jumlah tanaman dengan skor tertentu

$\mathrm{N}$ = Jumlah tanaman yang diamati (sampel)

$\mathrm{V}=$ Skor atau skala tertinggi

Tabel 1. Skor Gejala Penyakit.

\begin{tabular}{cl}
\hline Skor & \multicolumn{1}{c}{ Uraian } \\
\hline 0 & tidak terdapat bercak pada daun \\
1 & terdapat bercak sebanyak $1-25 \%$ pada \\
& $\begin{array}{l}\text { luasan daun } \\
\text { terdapat bercak sebanyak } 26-50 \% \text { pada } \\
\text { luasan daun }\end{array}$ \\
3 & $\begin{array}{l}\text { terdapat bercak sebanyak } 51-75 \% \text { pada } \\
\text { luasan daun }\end{array}$ \\
4 & $\begin{array}{l}\text { terdapat bercak sebanyak lebih } 75 \% \text { pada } \\
\text { luasan daun }\end{array}$ \\
\hline
\end{tabular}

(6) Pemanenan

Cara pemanenan setiap rumpun padi diambil dan ditimbang bobot biji per malai dengan menggunakan pisau. Biji padi dijemur di bawah sinar matahari agar mengurangi kadar air. Setelah itu, padi yang sudah kering dirontokkan dengan tangan. Setiap ulangan perlakuan ditimbang bobot biji padinya.

\section{HASIL DAN PEMBAHASAN}

Serangga yang ditemukan berasosiasi dengan tanaman padi pada hidroponik adalah belalang dan wereng (Gambar 1). Hanya ada 1 ekor serangga dari 12 sampel pengamatan. Oleh sebab itu, media tanam terlihat pengaruhnya terhadap intensitas serangan 
patogen pada tanaman padi. Adapun penyakit yang terdapat pada rumpun padi yang ditanam secara hidroponik adalah penyakit bercak daun sempit dan penyakit bercak coklat.

Intensitas Penyakit Bercak Daun Sempit. Hasil analisis ragam menunjukkan bahwa terdapat pengaruh media tanam pada sistem hidroponik tanaman padi terhadap intensitas serangan patogen. Pengaruh tersebut berupa perbedaan tingkat serangan patogen (Cercospora oryzae) pada berbagai media tanam yang digunakan. Hasil pengamatan menunjukkan bahwa keparahan penyakit bercak daun sempit tertinggi adalah pada perlakuan kontrol (tanah sawah) yakni 49,67\%. Selain itu, perlakuan lainnya yaitu pasir malang + arang sekam, pasir malang, dan arang sekam saja tidak berbeda dalam mempengaruhi keparahan penyakit bercak daun sempit yaitu persentase keparahannya sama antara 38\% hingga $43 \%$.

Intensitas Penyakit Bercak Cokelat. Hasil analisis ragam menunjukkan bahwa terdapat pengaruh penggunaan media tanam pada sistem hidroponik tanaman padi terhadap intensitas seranganbercak cokelat (Drechslera oryzae). Hasil pengamatan menunjukkan bahwa keparahan penyakit bercak cokelat tertinggi pada perlakuan kontrol yaitu media tanah sawah yaitu $45,33 \%$. Selain itu, nilai keparahan penyakit bercak coklat pada perlakuan pasir malang dan arang sekam

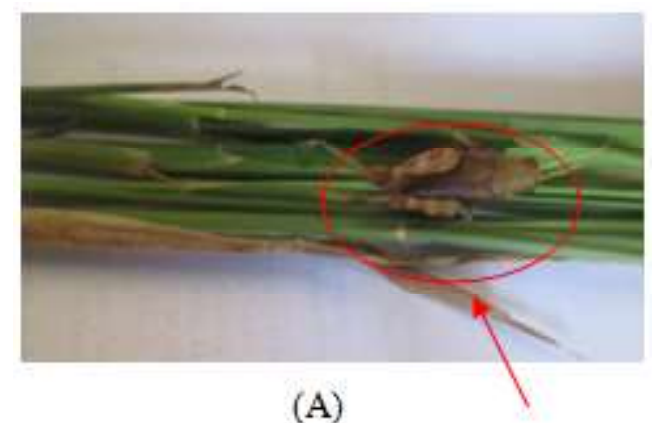

(A)

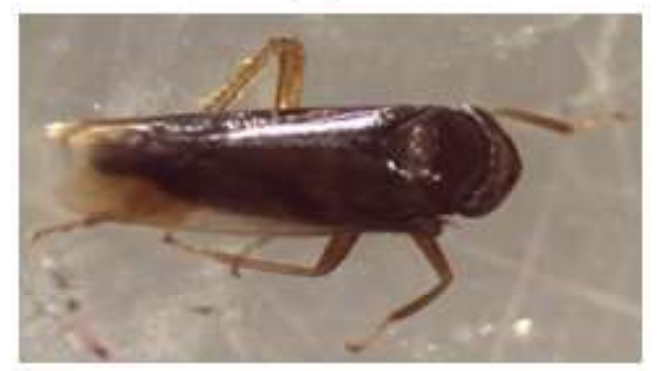

(B)

Gambar 1. Hama pada hidroponik padi yang ditemukan adalah (A). Belalang dan (B). Wereng (Perbesaran 100x).
$35,33 \%$ tidak berbeda nyata dengan perlakuan pasir malang 39,00\% dan arang sekam 34,00\%.

Bobot Biji Padi Hidroponik Pada Media Tanam. Bobot biji padi per malai dipengaruhi oleh jenis media tanamnya. Pada berbagai media tanam (arang sekam, pasir malang+arang sekam, pasir malang) menghasilkan bobot biji padi yang berbeda dengan kontrol. Antar media tanam tidak berbeda dalam bobot biji yaitu berkisar antara 5,42\% hingga $8,08 \%$ gram/ malai.

Proses budidaya padi tidak lepas dari pengaruh faktor internal dan eksternal tanaman. Faktor internal tanaman dipengaruhi sifat genetik dari tanaman padi. Faktor eksternal dipengaruhi oleh lingkungan tumbuh tanaman padi, seperti iklim, topografi, unsur hara tanah, faktor biotik seperti keberadaan organisme pengganggu tanaman. (Gardner, 1991 dalam Efendi, 2012). Faktor eksternal yang cukup mengganggu adalah hama dan penyakit. Oleh sebab itu, perlu diketahui seberapa besar tingkat intesitas keparahan penyakit pada proses budidaya alternatif dengan sistem hidroponik dengan berbagai media tanam.

Padi sistem hidroponik diduga faktor lingkungan tumbuhterjaga sehingga tidak terjadi serangan hama yang tinggi. Penanaman hidroponik dalam rumah kaca, diduga dapat mengurangi hama yang masuk dan menyerang tanaman padi tersebut.

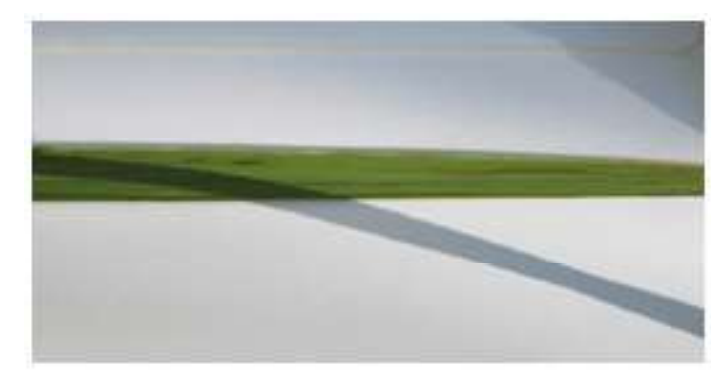

(A)

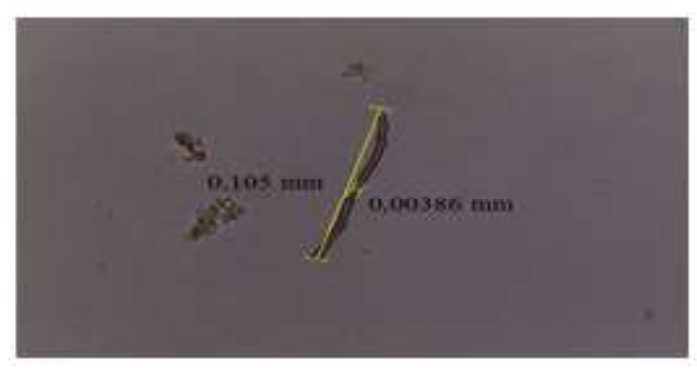

(B)

Gambar 2. Gejala penyakit bercak daun sempit pada daun padi (A) dan Konidia penyebab penyakit Cercosporaoryzae (B) 
Tabel 1. Pengaruh penggunaan berbagai media tanam terhadap intensitas serangan patogen bercak daun sempit pada tanaman padi hidroponik.

\begin{tabular}{lc}
\hline Perlakuan & $\begin{array}{c}\text { Keparahan Penyakit Bercak daun } \\
\text { sempit (\%) }\end{array}$ \\
\hline K & $49,67 \mathrm{a}$ \\
PM+AS & $43,00 \mathrm{~b}$ \\
PM & $41,00 \mathrm{~b}$ \\
AS & $38,00 \mathrm{~b}$ \\
\hline F-hit & $11,01^{* *}$ \\
\hline BNT 5\% & 5,52 \\
\hline
\end{tabular}

Keterangan: $\mathrm{K}=$ Kontrol, $\mathrm{PM}+\mathrm{AS}=$ Pasir Malang+Arang Sekam, PM = Pasir Malang, dan AS = Arang Sekam. Dua nilai tengah yang diikuti oleh huruf yang sama dinyatakan tidak berbeda nyata menurut uji BNT pada taraf 5\%

Tabel 6. Bobot biji padi hidroponik per malai pada media tanam.

\begin{tabular}{lc}
\hline Media Tanam & $\begin{array}{c}\text { Bobot Biji } \\
(\mathrm{g} / \text { malai })\end{array}$ \\
\hline AS & 8,08 a \\
PM+AS & 7,43 a \\
PM & 5,42 a \\
K & $0,67 \mathrm{~b}$ \\
\hline F-hit & $29,01^{* *}$ \\
\hline BNT 5\% & 2,37 \\
\hline
\end{tabular}

Keterangan: $\mathrm{K}=$ Kontrol, $\mathrm{PM}+\mathrm{AS}=$ Pasir Malang+Arang Sekam, PM = Pasir Malang, dan AS = Arang Sekam. Dua nilai tengah yang diikuti oleh huruf yang sama dinyatakan tidak berbeda nyata menurut uji BNT pada taraf 5\%

Hasil penelitian menunjukkan bahwa media tanam berpengaruh terhadap intensitas keparahan penyakit pada sistem tanam padi hidroponik. Media tanam arang sekam memiliki tingkat intensitas serangan penyakit yang lebih kecil dari media. Hal tersebut menunjukkan bahwa penggunaan media arang sekam pada sistem hidroponik tanaman padi lebih baik dalam penekanan keparahan penyakit jika dibandingkan dengan media lainnya.

Kandungan unsur hara dalam abu sekam yang mampu untuk menyuplai kebutuhan unsur hara tanaman sehingga tanaman menjadi kokoh dan kuat. Salah satu kandungan unsur hara pada abu atau arang sekam adalah $\mathrm{SiO}_{2}$. Kandungan $\mathrm{SiO}_{2}$ pada abu atau arang sekam padi
Tabel 2. Pengaruh penggunaan berbagai media tanam terhadap intensitas serangan patogen bercak cokelat pada sistem hidroponik tanaman padi.

\begin{tabular}{lc}
\hline Perlakuan & $\begin{array}{c}\text { Keparahan Penyakit Bercak } \\
\text { Coklat }(\%)\end{array}$ \\
\hline K & $45,33 \mathrm{a}$ \\
PM+AS & $35,33 \mathrm{bc}$ \\
PM & $39,00 \mathrm{~b}$ \\
AS & $34,00 \mathrm{c}$ \\
\hline F-hit & $21,88^{* *}$ \\
\hline BNT 5\% & 5,52 \\
\hline
\end{tabular}

Keterangan: $\mathrm{K}=$ Kontrol, $\mathrm{PM}+\mathrm{AS}=$ Pasir Malang+Arang Sekam, PM = Pasir Malang, dan AS = Arang Sekam. Dua nilai tengah yang diikuti oleh huruf yang sama dinyatakan tidak berbeda nyata menurut uji BNT pada taraf 5\%

berkisar antara $87 \%$-97\% (Hartono dkk., 2005). Selain itu, Martono (2001) menyatakan bahwa pemberian abu sekam yang banyak mengandung kandungan Silika mampu meningkatkan hasil tanaman dan menekan serangan hama dan penyakit pada tanaman tomat.

Penambahan $\mathrm{AB}$ mix pada pertanaman juga meningkatkan ketahanan terhadap serangan hama dan patogen pertanaman. Kandungan hara pada $\mathrm{AB}$ mix seperti larutan stok A, larutan stok B, dan asam dengan jumlah 15-20\% dari total larutan stok (Resh, 2004) dapat menyuplai kebutuhan hara. Kandungan pada arang sekam atau abu sekam yaitu silikon, $\mathrm{N}$, dan $\mathrm{K}$ juga mampu menyuplai unsur hara tanaman dan meningkatkan kandungan protein sehingga tingkat serangan patogen berkurang pada tanaman. Oleh sebab itu, penambahan $\mathrm{AB}$ mix dan penggunaan arang sekam mampu menjaga serangan patogen pada pertanaman padi hidroponik dibandingkan menggunakan media lain.

Bobot biji padi terendah ada pada media tanam kontrol dan tertinggi pada arang sekam. Pada media arang sekam nilai rata-rata 8,08 gram sedangkan pada media kontrol (tanah sawah) nilai rata - rata 0,67 gram. Hal ini menunjukkan bahwa media arang sekam lebih baik dibandingkan dengan media lain.

\section{KESIMPULAN}

Adapun kesimpulan yang dapat diambil yaitu patogen yang menyerang tanaman padi dengan sistem hidroponik pada berbagai media tanam adalah Cercospora oryzae penyebab penyakit bercak daun sempit dan Drechslera oryzae penyebab penyakit bercak 
cokelat. Serangga yang berhasil teridentifikasi adalah belalang dan wereng. Penggunaan media tanam abu sekam dengan sistem hidroponik memberikan intensitas serangan patogen lebih rendah dari media tanam lainnya pada dua jenis penyakit yang teridentifikasi.

Bobot biji padi terendah ada pada media tanam kontrol dan tertinggi pada arang sekam. Pada media arang sekam nilai rata-rata 8,08 gram sedangkan pada media kontrol (tanah sawah) nilai rata - rata 0,67 gram. Hal ini menunjukkan bahwa media arang sekam lebih baik dibandingkan dengan media lain.

\section{DAFTAR PUSTAKA}

Barnett, H.L. 1969. Illustrated Genera of Imperfect Fungi. Burgess Publishing Company. Ilinneapolis. $225 \mathrm{hlm}$.

BPS. 2014a. Profil kemiskinan di Indonesia September 2013. Berita Resmi Statistik Badan Pusat Statistik No. 06/01/Th. XVII, 2 Januari 2014. $8 \mathrm{hlm}$.

BPS. 2014 ${ }^{\text {b }}$ Produksi Padi (Angka Ramalan I Tahun 2014. Berita Resmi Statistik Badan Pusat Statistik No.50/07/Th. XVII, 1 Juli 2014. $10 \mathrm{hlm}$.

Efendi. 2012. Respon Pertumbuhan dan Produksi Plasma Nutfah Padi Lokal Aceh terhadap Sistem Budidaya Aerob. Jurnal Agrista. Vol.16(3): 114121.

Ginting, C. 2013. Ilmu Penyakit Tumbuhan. Lembaga Penelitian Universitas Lampung. Bandar Lampung. $245 \mathrm{hlm}$.

Hartono Y. M. V., W. Baraba., Suparta., A. R. Jumadi., dan Supomo. 2005. Pembuatan SiC dari Sekam Padi. Bandung: Balai Besar Penelitian dan Pengembangan Industri Keramik. Departemen Perindustrian dan Perdagangan. $421 \mathrm{hlm}$.
Jones, Jr. dan J. Benton. 2005. Hydroponics: A Practical Guide for the Soiless Grower. CRC Press. Florida. $631 \mathrm{hlm}$.

Lembaga Penelitian Padi Internasional. 1995. Permasalahan Tanaman Tentang Padi di Daerah Tropika. Penterjemah Kasumbogo Untung, Harsono Lanya, dan Yadi Rusyad. Los Banos. Filipina. $173 \mathrm{hlm}$.

Martono. 2001. Pengaruh Pupuk Organik Abu Sekam Padi terhadap Pertumbuhan dan Hasil Tanaman Kacng Tanah (Arachis hypogeae L.) Embryo. $11 \mathrm{hlm}$.

Nurbaity, A., Diyan, Herdiyantoro, dan M. Oviyanti. 2009. Pemanfaatan bahan organik sebagai bahan pembawa inokulan fungsi mikoriza arbuskula. Jurnal Biologi. Vol.8(1): 11-17.

Program Kreatifitas Mahasiswa. 2014. Pengaruh Berbagai Media Tanam pada Pertumbuhan Padi (Oryza sativa L.). dengan Sistem Hidroponik. Fakultas Pertanian Universitas Lampung. Bandar Lampung.

Resh, H.M. 2004. Hydroponic Food Production 6th Edition: A Definitife Guide Book for The Advanced Home Gardener and The Comercial Hydroponic Grower. New Concept Press. Mahwah, New Jersey. $567 \mathrm{hlm}$.

Semangun, H. 1996. Ilmu Penyakit Tanaman. Gadjah Mada University Press. Yogyakarta.42-48 hlm.

Siswandi dan Yuwono. 2013. Uji Hasil Tanaman Sawi Pada Berbagai Media Tanam Secara Hidroponik. Jurnal Inovasi Pertanian. Vol.11 (1) 44-50 Hlm.

Tim Tani Mandiri. 2010. Pedoman Budidaya Secara Hidroponik. Bandung. CV. Nuansa Aulia.162 hlm. 